\title{
Democracias Andinas: Chegando Tarde à Festa?*
}

\author{
Marcelo Coutinho
}

\section{INTRODUÇÃO}

$\mathrm{E}$ ste artigo pretende examinar as condições socioeconômicas e políticas dos países andinos na virada do século XX para o XXI, em busca de uma explicação para a instabilidade política que então caracteriza essa parte da América do Sul. A suposição inicial é a de que a resposta para as crises institucionais está em uma contradição fundamental enfrentada pelos estados andinos contemporâneos, a qual, ao se traduzir em fonte prioritária da insatisfação de amplos setores da sociedade com o desempenho substantivo da democracia, gera tipos variados de comportamento desagregador.

Um aspecto compartilhado pelos casos examinados e que se destaca é a fragmentação social. Ela manifesta-se de diferentes formas e níveis, indo da guerra civil colombiana ao conflito despertado por populações tradicionais, regiões e sindicatos na Bolívia, Equador e Peru, passando pela divisão da sociedade venezuelana. Todas as suas formas de manifestação, porém, têm em comum um fracionamento estrutural defla-

\footnotetext{
*Este artigo é resultado de pesquisas desenvolvidas no âmbito do Observatório Político Sul-Americano - OPSA do Instituto Universitário de Pesquisas do Rio de Janeiro - Iuperj, e contou, especialmente, com a valiosa assistência de Juan Claudio Epsteyn, doutorando em ciência política e responsável pela coleta e organização dos dados socioeconômicos. Gostaria ainda de agradecer aos pareceristas anônimos da revista Dados pelos enriquecedores comentários e sugestões à primeira versão deste texto.
}

DADOS - Revista de Ciências Sociais, Rio de Janeiro, Vol. 49, n-4 4, 2006, pp. 795 a 832. 
grado por hostilidades intensas entre grupos políticos e sociais que com freqüência resvalam para a violência.

Não obstante as diferenças observadas caso a caso, em alguma medida toda a região andina ressente-se de um desequilíbrio institucional provocado pela polarização de forças, cujo resultado são crises periódicas, enfraquecimento de governos, recrudescimento de regimes, falta de regras claras de convivência, enfim, um clima de intranqüilidade e tensão permanente que obstaculiza a ordem democrática ao mesmo tempo em que revela sua centralidade.

Esse estado crítico em que vivem os Andes, que os uniformiza sem, contudo, eliminar suas especificidades, precisa ser analisado primeiro no contexto de democratização e liberalização econômica crescente do mundo desde as últimas décadas do século XX. Os países andinos talvez sejam os que mais claramente expressem nesse período a contradição existente entre a liberdade de participar e contestar dos povos e a dificuldade destes serem atendidos em uma época em que o Estado nacional perde em autonomia. Em outras palavras, já tendo experimentado o Estado oligárquico, o Estado populista e diversas variações de estados autoritários e plutocracias, a América Latina passou nas últimas décadas a transitar para um Estado democrático-liberal. Esse novo modelo abriga uma grande incoerência porque a democratização do Estado ocorre em um momento em que ele não pode ou simplesmente abriu mão de ser instrumento de mudanças na estrutura social. O que entra em crise e se reforma nos anos 1980 e 1990 é o próprio Estado. A assimetria das estruturas sociais é preservada.

A novidade desta vez é que movimentos populares crescentes não podem mais ser simplesmente ignorados ou reprimidos sem maiores conseqüências. A contradição do novo Estado consiste em ser mais democrático, porém menos capaz, em permitir a participação e a contestação pública - segundo eixos dahlseanos (1971) -, com menos condições para satisfazê-las porque estas foram em grande parte transferidas para o mercado, que se globalizou, se tornou mais complexo e demora a apresentar resultados mais positivos.

Um quadro geral, no entanto, pode dar a impressão equivocada de que os Andes são um bloco homogêneo, o que não é verdade. Cada país desenvolve um processo político particular, ainda que todos eles tenham semelhanças e possam ser examinados em conjunto sobre determinado ponto de vista. Suas especificidades, bem como seus componentes 
de instabilidade e governo em comum, serão mais detalhadamente estudados em três partes deste artigo - as duas primeiras referem-se às condições socioeconômicas, e a terceira trata de conflitos e instituições políticas -, após as quais se seguirão algumas conclusões finais. Cabe ressaltar que a divisão das condições socioeconômicas em duas seções obedecerá a um critério preliminar às vezes presente no debate público de forma distorcida, entre variáveis desenvolvimentistas e liberais.

\section{CONDIÇÕES SOCIOECONÔMICAS: VARIÁVEIS "DESENVOLVIMENTISTAS"}

Os primeiros anos do novo século repetem o quadro de dificuldades econômicas e sociais secular na região. Analisado o período pós-transição democrática, observa-se um crescimento econômico modesto e muito oscilante (cf. Tabela 1). A média de 1980 a 2005, sendo este último dado ainda apenas uma estimativa, foi de pouco mais de 2,2\%. A Colômbia teve o melhor desempenho $(3,0 \%)$ e a Venezuela, o pior deles (1,3\%). Há anos de crescimento negativo (1982, 1983, 1989 e 1999), e em apenas cinco oportunidades a região cresceu acima de 4\% (1986, 1991, 1994, 1995 e 2004).

Examinando os casos separadamente, observa-se que os anos 1990 não foram tão ruins para a Bolívia. Cresceu a maior parte do tempo acima de 4\%, caindo o PIB apenas em 1999, mas voltando a recuperar-se logo nos anos seguintes, ainda que com menos intensidade. Os anos 1980 foram, sem dúvida, os piores para este país. Com isso, a série histórica demonstra uma certa tendência positiva, embora também apresente um teto de 5,3\% (1991) e uma média geral baixa de 2,0\% .

A Colômbia, por sua vez, manteve sempre um saldo positivo até 1999 . Até este ano, quando experimentou crescimento fortemente negativo de $-4,2 \%$, havia apresentado desempenho próximo a zero apenas em 1982 e 1998. Seus melhores anos são de 1986 a 1995, alcançando, por sinal, seu maior pico em 1990, quando obteve um crescimento de 6,0\% do PIB. Apresenta, assim, a melhor performance individual de todos os países andinos nesse quesito.

O Equador teve seu melhor momento na passagem da década de 1980 para a de 1990, quando alcançou sua mais elevada expansão no PIB $(8,4 \%)$. Voltou a ter um bom desempenho após a crise de 1999, ano em que retraiu $6,3 \%$. Aliás, este foi um ano ruim para todos os países andinos, mergulhados em recessão assim como no segundo e terceiro anos 
Marcelo Coutinho

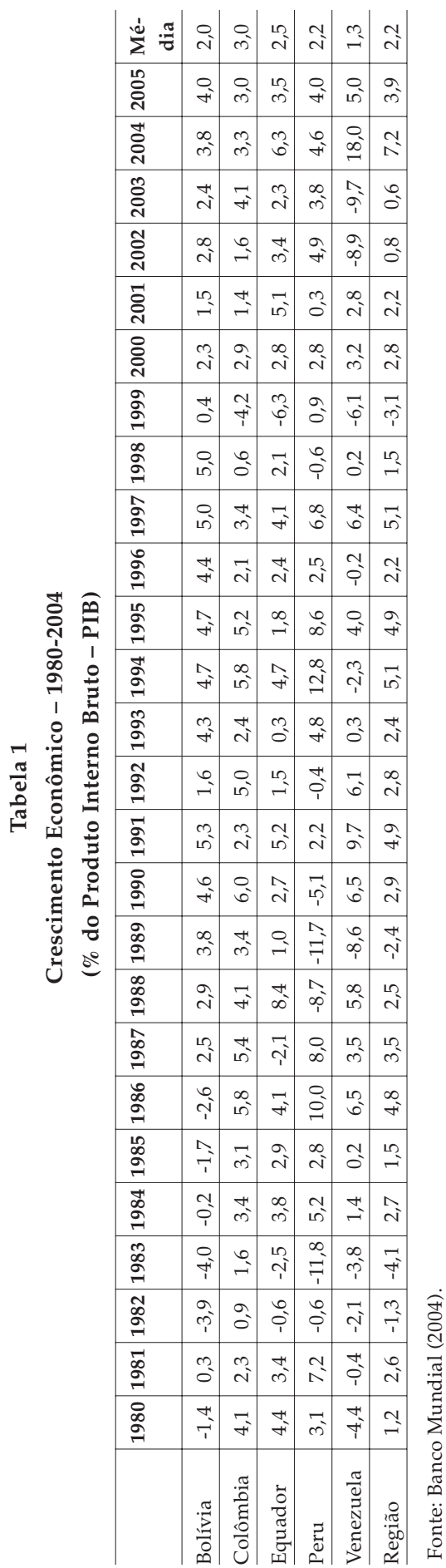


da década de 1980. O Equador tem tido a melhor atuação geral nos últimos anos, melhor até mesmo que a Colômbia.

O Peru apresentou um dos quadros de crescimento mais instáveis. Por duas vezes nos anos 1980 obteve um crescimento negativo de quase 12\% (1983 e 1989), os piores de toda a região. Por outro lado, cresceu 12,8\% em 1994, o segundo maior pico na série andina. Após momentos de grande prosperidade seguiram-se períodos de crise profunda. Nos quatro últimos anos vem apresentando um crescimento relativamente positivo, com viés ascendente, ainda que mais modesto do que os períodos de 1984 a 1987 e 1993 a 1997.

O crescimento venezuelano, por sua vez, um dos mais instáveis na região junto com o do Peru, destacou-se por registrar o maior salto individual, de 18\%, em 2004. Esse recorde foi, em grande medida, decorrente de uma forte recuperação da crise de 2002 e 2003, anos em que o país decresceu a taxas de $9 \%$, o pior desempenho andino, comparado apenas à crise peruana no final da década de 1980, quando também a Venezuela passou por maus momentos. Com isso, não é possível traçar qualquer tendência para o país, mesmo considerando os anos mais recentes, que não a de novas oscilações radicais.

O baixo crescimento econômico médio nos Andes acompanha um aumento do desemprego urbano, que, em toda série histórica, gira em torno de 10\% (cf. Tabela 2). Segundo pesquisa da Organização Internacional do Trabalho - OIT, após uma ligeira queda entre os anos 1993 e 1995, o desemprego cresceu, consistentemente, até superar os 12\% em 2003. Este patamar foi excedido apenas em 1999, quando o desemprego regional atingiu sua maior marca $(13,2 \%)$. Individualmente, embora seja o país que mais expandiu o PIB nesse período, a Colômbia tem a maior taxa média de desemprego $(13,5 \%)$, seguida da Venezuela $(12,1 \%)$, que, como já foi visto, apresentou o pior desempenho econômico. A menor taxa média de desemprego é a da Bolívia, abrangendo apenas 6,3\%, o que é consistente com seu relativo bom desempenho no PIB ao longo dos anos 1990.

A Bolívia não apenas apresenta as menores taxas médias de desemprego como também a segunda menor tendência de alta. Contudo, desde 2003, o desemprego ultrapassou os 9\%, aproximando-se do Peru, que tem as taxas mais estáveis da região, sobretudo nos últimos anos, ao redor de 9,5\%. Já o Equador, que também está pouco abaixo da média ge- 
Marcelo Coutinho

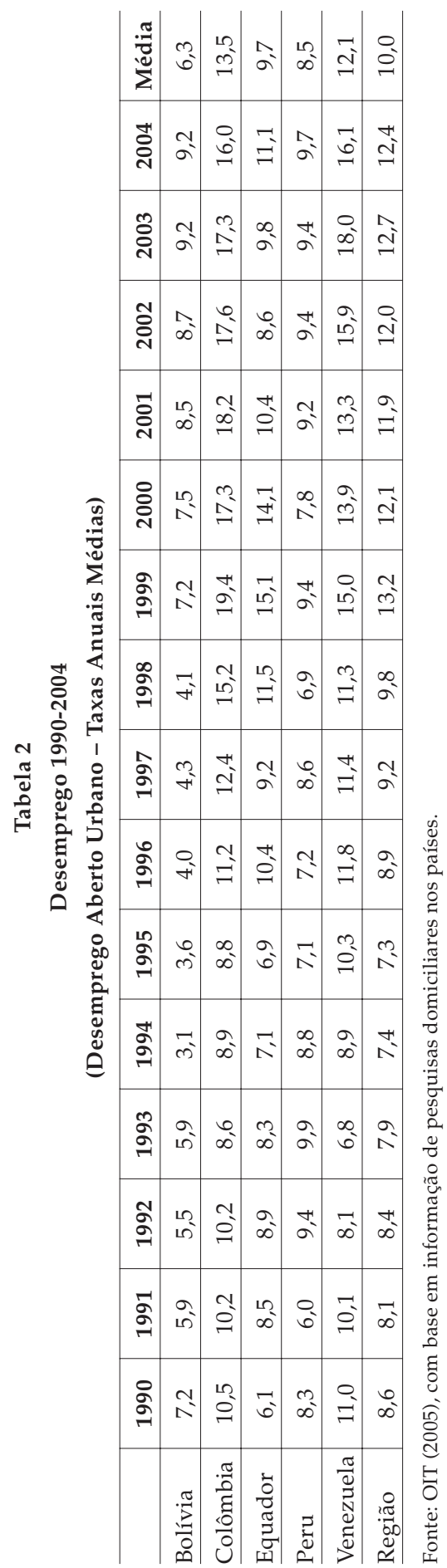


ral de desemprego, depois de alguns anos críticos na passagem da década, assistiu em 2001 a uma queda acentuada nessas taxas, juntando-se, assim, à Bolívia e ao Peru.

De todos os países, Colômbia e Venezuela são aqueles onde mais facilmente se observa um crescimento significativo do desemprego. Ambos partem, em 1990, de uma taxa de $10,5 \%$ a $11 \%$, chegando a $16 \%$ em 2004, um aumento, portanto, de 5\% em 15 anos. O Equador também ampliou o desemprego com intensidade semelhante, mas em um patamar bem inferior. Existe uma grande oscilação, mas é possível dizer que a Colômbia ao menos apresenta um leve viés de melhora após o salto de 19,4\% em 1999, por sinal, o maior desemprego de toda esta região.

O aumento do desemprego urbano também é consistente com o crescimento médio da população nas cidades, embora apresente variações importantes entre os países (cf. Tabela 3). Todos os países andinos já são predominantemente urbanos no início da década de 1990. Em geral, entre 1990 e 2004, há um crescimento por volta de $7 \%$ da população urbana, atingindo uma taxa média regional na série histórica de quase $60 \%$. A série mais estável é a equatoriana, que, aliás, apresenta a menor taxa de crescimento populacional urbano entre o grupo dos andinos. O crescimento mais acentuado ocorre na Venezuela (justamente o país com maior crescimento do desemprego) e, logo em seguida, no Peru (onde o desemprego cresce menos), ambas populações urbanas já superando inclusive dois terços do total. O crescimento das cidades é mais atenuado na Colômbia, onde, no entanto, o desemprego aumentou muito desde 1990, e na Bolívia, onde, ao contrário, aumentou pouco.

A combinação de baixo crescimento econômico e aumento do desemprego, agora significativamente mais urbano, parece congelar o cenário social andino nas últimas décadas, mas apresentando resultados dúbios. Em geral, os indicadores de pobreza e desigualdade social são menos periódicos e seguros que os anteriores já analisados (cf. Tabelas 4 e 5). Mas tudo indica, inclusive a análise de relatórios oficiais e internacionais, que persiste uma enorme dívida social nesses países. A pobreza continua muito elevada e a desigualdade social permanece como sendo uma das piores do mundo, a exemplo do restante da América do Sul, sem sinais de melhora consistente e significativa nesse aspecto a não ser nos últimos três anos. Na melhor das hipóteses, a pobreza teria 


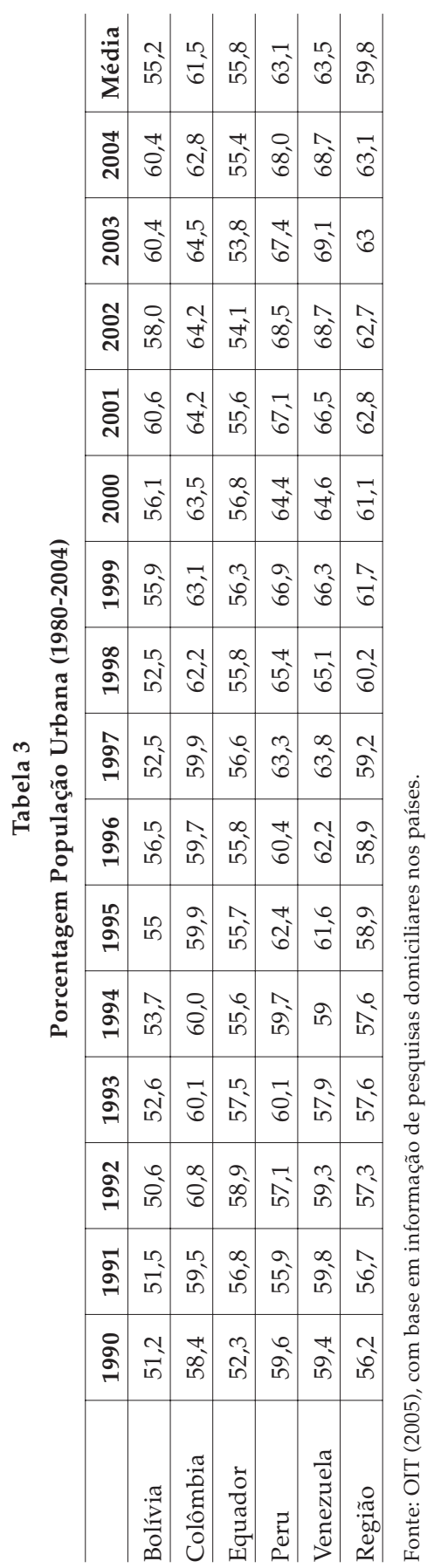


diminuído um pouco, marginalmente, enquanto as assimetrias teriam até mesmo expandido em alguns casos.

Tabela 4

Pobreza (1990-2002)

\begin{tabular}{l|c|c|c|c|c}
\hline & $\mathbf{1 9 9 0}$ & $\mathbf{1 9 9 4}$ & $\mathbf{1 9 9 7}$ & $\mathbf{1 9 9 9}$ & $\mathbf{2 0 0 2}$ \\
\hline Bolívia & - & & 62,1 & 60,6 & 62,4 \\
\hline Colômbia & 56,1 & 52,5 & 50,9 & 54,9 & 51,1 \\
\hline Equador (zonas urbanas) & 62,1 & 57,9 & 56,2 & 63,5 & 49,0 \\
\hline Peru & - & & 47,6 & 48,6 & 54,8 \\
\hline Venezuela & 39,8 & 48,7 & 48 & 49,4 & 48,6 \\
\hline
\end{tabular}

Fonte: CEPAL (2006).

Tabela 5

Desigualdade Social

(Gini)

\begin{tabular}{l|c|c|c|c}
\hline & $\mathbf{1 9 8 1}$ & $\mathbf{1 9 9 8}$ & $\mathbf{1 9 9 9}$ & $\mathbf{2 0 0 0}$ \\
\hline Bolívia & - & & 44,7 & 45,0 \\
\hline Colômbia & & & 57,6 & - \\
\hline Equador & - & 43,7 & - & \\
\hline Peru & - & & & 49,8 \\
\hline Venezuela & 55,6 & 49,1 & - & \\
\hline
\end{tabular}

Fonte: Banco Mundial (2004).

Segundo a Comissão Econômica para a América Latina e o Caribe-Cepal (2006), a tendência à melhora nos índices de pobreza em 2005 foi conseqüência principalmente do crescimento econômico verificado na América Latina. No ano de 2004, o crescimento médio nesses países foi de 5,9\%, e, em 2005, foi de 4,7\%. O relatório da Cepal argumenta que a recuperação econômica teve um impacto positivo sobre os mercados de trabalho e, da mesma forma, sobre a diminuição da pobreza, apesar do crescimento da informalidade em vários países. Outro fator salientado foi o baixo índice de inflação (8,5\% em 2003 e 7,3\% em 2004), que teve um impacto positivo sobre o poder de compra dos mais pobres.

O país mais pobre entre os andinos continua sendo a Bolívia, com mais de $60 \%$ da população nessa situação, seguido do Peru e depois da Colômbia, Equador e Venezuela. Há um agravamento do quadro social 
venezuelano no início dos anos 1990 e, possivelmente, em 2002 e 2003, anos da crise. Uma análise preliminar mostra ainda um viés de piora no Peru no mesmo ano, mas, por outro lado, também uma queda brusca da pobreza no Equador e uma queda menor na Colômbia.

Outra condição estrutural andina que não só permaneceu quase intocada, como também se agravou em alguns casos, foi a dívida pública (cf. Tabelas 6 e 7). A Colômbia foi o país onde mais ela cresceu nos anos 1990 e no início dos anos 2000, chegando mesmo a duplicar. No Peru, a dívida também cresceu bastante neste período. Já no Equador e na Bolívia ela cresceu menos, porém com uma tendência de alta importante. A dívida manteve-se praticamente estável na Venezuela, com algumas oscilações. Em termos absolutos, as menores dívidas regionais são a boliviana ( 5,4 bilhões de dólares) e a equatoriana ( 16,8 bilhões de dólares), enquanto as maiores são a colombiana ( 38,7 bilhões de dólares), venezuelana (33,2 bilhões de dólares) e peruana ( 29,7 bilhões de dólares).

De 1995 a 2004, a média regional da relação dívida/PIB diminuiu de $53,6 \%$ para $48,6 \%$, variando em torno de $49 \%$ nesta série histórica. Isso significa que o crescimento econômico foi baixo, mas um pouco superior ao crescimento da dívida, que já não compromete a metade das riquezas produzidas na maior parte desses países. O pior desempenho nesse sentido é, sem sombra de dúvida, o da Bolívia, onde a dívida já ocupou $79 \%$ do PIB nacional, variando dentro de uma média individual de 59,6\%. Neste país, a relação dívida/PIB caiu bastante entre 1996 e 2002, voltando a subir bruscamente em 2003.

Nos demais países, essa relação é mais equilibrada e inferior a 50\%. Na Colômbia, a tendência é de alta. Na Venezuela, também, mas somente a partir de 2002 (ano de crise), após cair bastante entre 1997 e 2001. Já no Peru e no Equador, o peso da dívida sobre o PIB vem diminuindo consistentemente, sobretudo depois de 1999. Ambos os países tinham, em 1995, mais de $60 \%$ da dívida compreendida no PIB. O Equador chegou a bater o recorde em 1999, com $82 \%$, atingindo, em 2004, no entanto, a menor taxa de todos os andinos (36,9\%). O Peru também diminuiu cerca de 20\% o peso de sua dívida sobre o PIB, reduzindo-o para 43,3\% em 2004.

Se o endividamento público continua sendo um grande problema nos Andes, a falta de investimentos diretos nessa região agrava o quadro ainda mais (cf. Tabelas 8 e 9). O investimento produtivo externo nesses países é, de fato, muito baixo e oscilante. Cresceu em alguns anos na 
Democracias Andinas: Chegando Tarde à Festa?
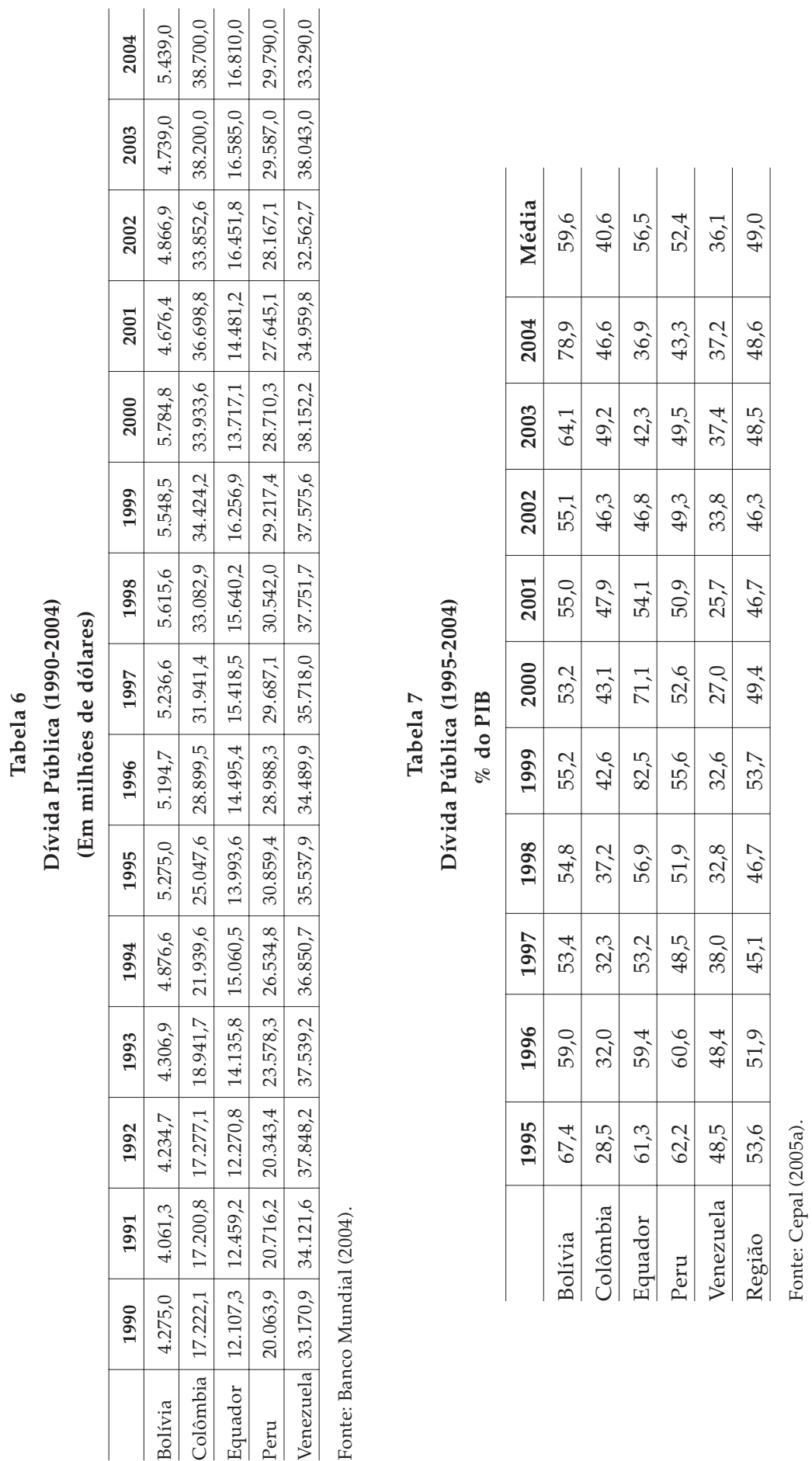


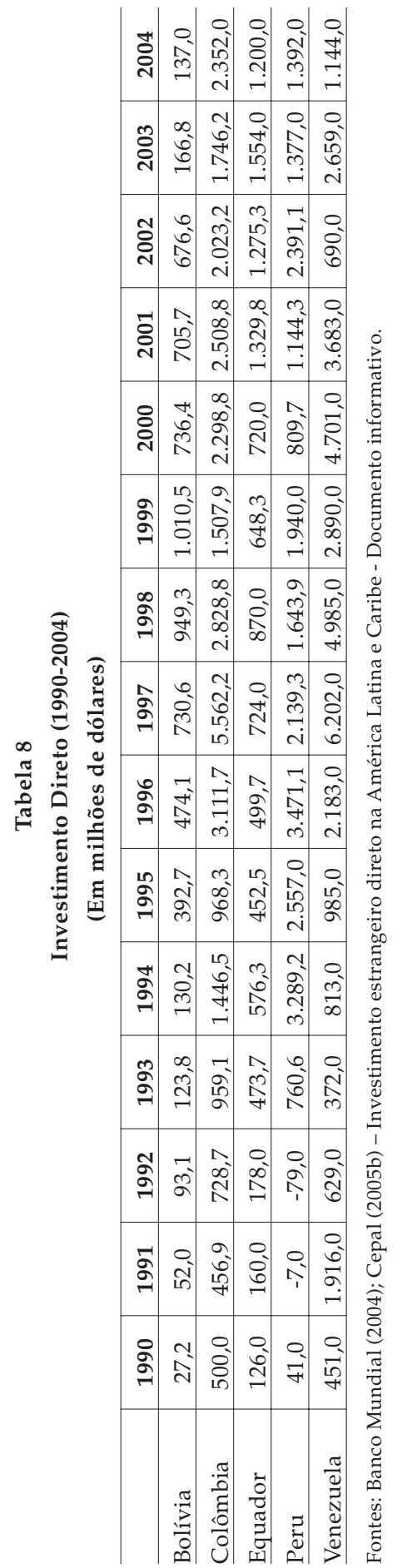

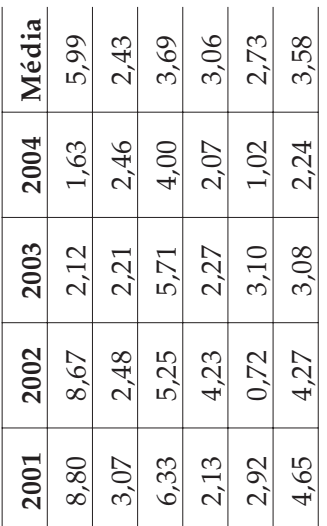

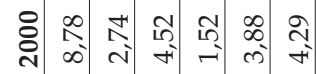

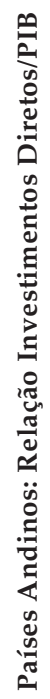

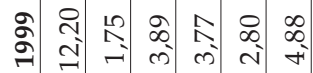

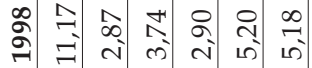

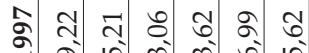

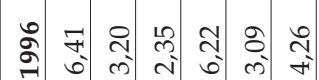

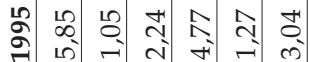

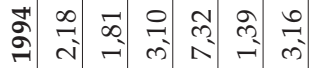

ڤ̊

ลิ นี

Б̊

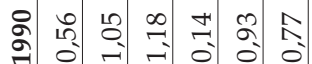

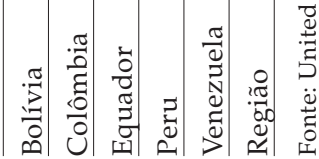


metade da década de 1990, mas voltou a cair logo depois disso para patamares quase insignificantes. Os países que mais aproveitaram este breve ciclo de inversões em termos absolutos foram Colômbia e Venezuela. O Equador, embora não tenha grandes investimentos, os vê aumentando mais consistentemente. O Peru passou por um bom momento entre 1993 e 1996 e tornou a se recuperar em 2000, mas de maneira bastante instável. Os investimentos externos subiram na Bolívia até 2000/2001, começando então a decair sensivelmente.

O volume dos investimentos diretos nos Andes com relação ao PIB é mínimo. Poucas vezes ultrapassa 5\%. A média na região de 1990 a 2004 é de 3,58\%. Claramente, o peso relativo dos investimentos cresce até 1997, depois decresce de forma acentuada. O investimento regional parte de um patamar inferior a $1 \%$ em 1990, o que permite que seja facilmente dobrado ou mesmo triplicado, mas, ainda assim, mantendo-se baixo. Ao contrário do que ocorre com os números absolutos, a Bolívia aparece com o maior crescimento do percentual de investimentos com relação a seu PIB. Portanto, apesar de se investir mais na Venezuela e na Colômbia do que na Bolívia, neste país o peso relativo dos investimentos é bem maior entre 1995 e 2002. Por outro lado, o Equador demonstra, também em função do seu produto interno bruto, um crescimento sustentável até 2001, quando começa a oscilar negativamente.

Considerando todos os aspectos socioeconômicos até aqui vistos, o quadro é mesmo pouco animador. O crescimento econômico foi pequeno, e o aumento incipiente nos investimentos produtivos sobre o PIB muito aquém até mesmo para os padrões sul-americanos - não foi sequer duradouro. As cidades expandiram-se e o desemprego, junto com elas. A dívida social (pobreza e desigualdade) arrastou-se, embora tenha havido alguns avanços, tal qual na dívida pública.

Individualmente, a Bolívia teve melhores indicadores de crescimento e emprego comparada aos outros países andinos nos anos 1990, mas endividou-se muito nesse período. Além disso, continuou sendo um país muito pobre e desigual, o mais pobre dessa sub-região. O valor dos investimentos em relação à riqueza interna produzida teve um aumento significativo em alguns anos, mas despencou novamente em 2003 e 2004. A falta de novos investimentos produtivos externos levou a um endividamento extraordinário. Já a Colômbia foi a que mais cresceu em termos médios em toda a série histórica, incluindo os anos 1980, ainda que em níveis insuficientes como mostra o aumento do desem- 
prego no país. O endividamento colombiano não supera os $50 \%$ do PIB, mas vem crescendo. Ademais, as taxas de investimento são muito baixas e não-sustentáveis.

Algo parecido ocorre com os investimentos na Venezuela. No entanto, neste país, a dívida é relativamente menor com relação ao PIB e seus vizinhos. O desemprego tem aumentado, acompanhando grandes oscilações no crescimento econômico. Conseqüentemente, na melhor das hipóteses, a pobreza e a desigualdade persistiram. No Peru, o crescimento econômico é altamente instável, mas apresentou alguma melhora nos anos 2000. O desemprego esteve levemente em alta, mas, apesar do quadro social permanecer ruim, a dívida pública relativa ao PIB diminuiu sensivelmente. Por outro lado, caíram bastante os investimentos depois de subirem em 1994 e 1997.

Finalmente, o Equador cresceu a uma taxa média de 2,5\%, pouco superior à média geral dos Andes. Neste país, o desemprego aumentou como nos demais, porém ligeiramente abaixo da média. Teve a vantagem de diminuir de forma progressiva o seu endividamento ao mesmo tempo em que apresentou uma tendência de alta nas taxas de investimento com relação ao PIB. Nesse sentido, pode-se dizer que seja o país, no cômputo geral mais recente, com a melhor situação socioeconômica entre os vizinhos andinos.

\section{CONDIÇÕES SOCIOECONÔMICAS: VARIÁVEIS "LIBERAIS"}

Uma divisão entre variáveis desenvolvimentistas e liberais na análise das condições socioeconômicas, que, por vezes, rivalizam linhas de pensamento sobre a política macroeconômica, pode produzir distorções graves. Mesmo a inflação, cujo zelo costuma ser associado a correntes monetaristas e ortodoxas e, genericamente, mais liberais, tem também implicações para o desenvolvimento. Esse indicador estaria, a princípio, no rol das variáveis liberais e não nas desenvolvimentistas porque seu controle leva a uma redução do crescimento econômico. Ademais, o foco no controle da inflação verificado na segunda metade dos anos 1980 e ao longo dos anos 1990 na América do Sul coincidiu com a hegemonia do ideário neoliberal na região, o que acabou associando a ele o combate à disparada inflacionária.

De fato, em certos contextos, a exigência de taxas inflacionárias baixas e declinantes pode surtir efeitos negativos sobre o crescimento no curto prazo. Mas, em contrapartida, no longo prazo pode significar um 
crescimento mais duradouro e equilibrado, ao menos em tese. Além disso, inflação pequena e crescimento sustentado, ainda que moderado, devem produzir efeitos positivos sobre a distribuição de renda, um indicador fundamental de desenvolvimento.

Tabela 10

Comunidade Andina: Índice de Preços ao Consumidor

(Taxa de Variação Anual \%)

\begin{tabular}{l|c|c|c|c|c|c|c|c|c|c|c}
\hline & $\mathbf{1 9 9 5}$ & $\mathbf{1 9 9 6}$ & $\mathbf{1 9 9 7}$ & $\mathbf{1 9 9 8}$ & $\mathbf{1 9 9 9}$ & $\mathbf{2 0 0 0}$ & $\mathbf{2 0 0 1}$ & $\mathbf{2 0 0 2}$ & $\mathbf{2 0 0 3}$ & $\mathbf{2 0 0 4}$ & Média \\
\hline Bolívia & 11,9 & 7,7 & 6,6 & 4,3 & 3,1 & 3,4 & 0,9 & 2,4 & 3,9 & 4,6 & 3,04 \\
\hline Colômbia & 18,0 & 19,8 & 16,4 & 15,6 & 8,9 & 8,8 & 7,6 & 7 & 6,5 & 5,5 & 7,08 \\
\hline Equador & 20,7 & 23,0 & 27,1 & 36,8 & 49,1 & 91 & 22,4 & 9,4 & 6,1 & 2,0 & 26,18 \\
\hline Peru & - & 10,84 & 6,11 & 5,76 & 2,46 & 3,5 & $-0,5$ & 1,1 & 2,4 & 3,7 & 2,04 \\
\hline Venezuela & 45,1 & 74,2 & 31,5 & 25,2 & 17,3 & 13,4 & 12,3 & 31,2 & 27,1 & 19,2 & 20,64 \\
\hline Região & 23,9 & 27,1 & 17,5 & 17,5 & 16,2 & 17,1 & 8,0 & 10,9 & 9,8 & 7,6 & 10,68 \\
\hline
\end{tabular}

Fonte: Dados disponíveis em http:/ / www.comunidadandina.org.

Observando os países andinos na passagem do século XX para o XXI, verifica-se uma queda forte, inequívoca e regular dos índices de preço ao consumidor (cf. Tabela 10). Apenas no Equador, após 1997, a inflação sofre um aumento brusco, e na Venezuela, em 2002 (ano da crise). No geral, ela diminui bastante. Com exceção das taxas venezuelanas, que continuam relativamente altas, todos os países chegam em 2004 com uma inflação de apenas um dígito. No último ano da série, a média regional é de $7,6 \%$, variando em torno de 10,6\% nos 10 anos analisados.

Uma das médias mais baixas é a da Bolívia (3\%), justamente o país que teve o melhor crescimento econômico e de emprego nos anos 1990, embora mantivesse suas dívidas pública e social. O Peru teve uma média ainda menor (2\%) que coincide com a época em que seu crescimento econômico começou a melhorar, a partir de 2000. Por sua vez, as médias inflacionárias mais elevadas no Equador e na Venezuela não acompanharam taxas de crescimento econômico e investimento produtivo superiores aos demais países, ao menos significativamente. Ao contrário, o momento em que o Equador melhor esteve, em termos de crescimento, emprego e dívida, foi quando a inflação declinou fortemente. $\mathrm{O}$ mesmo não pode ser dito, no entanto, da Colômbia, onde a queda contínua das taxas de inflação pouco ou nada repercutiu favoravelmente no desempenho econômico do país.

Outra variável comumente associada ao neoliberalismo é o comércio exterior. Embora esta tenha sido uma variável fundamental no modelo 
nacional desenvolvimentista, seja em sua etapa de substituição de importações seja em sua fase mais internacionalista, costuma-se associá-la à agenda de reformas em direção ao mercado por causa dos choques de abertura comercial e liberalização que marcaram os anos 1990. Isso de fato ocorreu, com maior ou menor intensidade, mas nada impedia que o comércio fosse também um instrumento de desenvolvimento desde que obedecesse a critérios como a ampliação do mercado interno, aumento equilibrado da renda per capita e industrialização da economia.

O comércio só pode ser considerado uma variável estritamente liberal e não-desenvolvimentista quando sua abertura torna a economia nacional menos diversificada, competitiva, justa e produtiva. Uma das formas freqüentes na América do Sul de o comércio não promover o desenvolvimento é tornando ou preservando a natureza primário-exportadora de suas economias, o que as caracteriza historicamente. Mas, ainda assim, não há nada inerente ao comércio externo que diga que o protecionismo seja desenvolvimentista per se, da mesma maneira que sua abertura não possa servir a um projeto de desenvolvimento.

Tabela 11

Trocas Comerciais - Importações (1990-2004)

(Em milhões de dólares)

\begin{tabular}{c|c|c|c|c|c}
\hline & Bolívia & Colômbia & Equador & Peru & Venezuela \\
\hline 1990 & 702.698 & 5.588 .741 & 1.861 .745 & 2.633 .972 & 7.268 .571 \\
\hline 1991 & 992.432 & 4.966 .993 & 2.399 .035 & 3.475 .727 & 11.046 .106 \\
\hline 1992 & 1.115 .016 & 6.685 .947 & 2.416 .816 & 3.789 .955 & 13.154 .435 \\
\hline 1993 & 1.176 .703 & 9.840 .589 & 2.552 .715 & 4.191 .071 & 11.639 .926 \\
\hline 1994 & 1.196 .303 & 11.203 .236 & 3.649 .656 & 5.628 .566 & 8.398 .881 \\
\hline 1995 & 1.434 .077 & 13.206 .711 & 4.192 .693 & 7.581 .546 & 11.248 .634 \\
\hline 1996 & 1.643 .051 & 14.054 .580 & 3.931 .495 & 7.772 .515 & 9.306 .243 \\
\hline 1997 & 1.892 .032 & 15.480 .818 & 4.954 .669 & 8.364 .717 & 14.245 .652 \\
\hline 1998 & 2.382 .278 & 14.678 .218 & 5.503 .017 & 8.097 .528 & 15.048 .190 \\
\hline 1999 & 2.098 .113 & 10.659 .121 & 2.815 .026 & 6.531 .145 & 13.319 .601 \\
\hline 2000 & 1.976 .611 & 11.538 .510 & 3.568 .700 & 7.400 .771 & 15.278 .107 \\
\hline 2001 & 1.707 .755 & 12.813 .183 & 5.298 .858 & 7.291 .481 & 17.667 .218 \\
\hline 2002 & 1.770 .076 & 12.668 .089 & 6.431 .065 & 7.491 .508 & 10.647 .728 \\
\hline 2003 & 1.600 .782 & 12.853 .341 & 6.534 .400 & 8.700 .199 & 9.035 .074 \\
\hline 2004 & 1.595 .000 & 15.340 .000 & 7.650 .000 & 9.600 .000 & 14.980 .000 \\
\hline
\end{tabular}

Fonte: Cepal (2004). 
Tabela 12

Trocas Comerciais - Exportações (1990-2004)

(Em milhões de dólares)

\begin{tabular}{c|c|c|c|c|c}
\hline & Bolívia & Colômbia & Equador & Peru & Venezuela \\
\hline 1990 & 922.944 & 6.765 .037 & 2.714 .383 & 3.312 .752 & 17.692 .066 \\
\hline 1991 & 850.751 & 7.244 .282 & 2.851 .356 & 3.275 .258 & 15.190 .254 \\
\hline 1992 & 705.393 & 7.071 .662 & 3.057 .297 & 3.359 .592 & 14.184 .239 \\
\hline 1993 & 751.313 & 7.123 .446 & 3.061 .922 & 3.344 .406 & 15.458 .935 \\
\hline 1994 & 1.040 .568 & 8.407 .696 & 3.725 .055 & 4.361 .377 & 16.717 .452 \\
\hline 1995 & 1.137 .610 & 9.758 .439 & 4.361 .326 & 5.441 .375 & 17.204 .249 \\
\hline 1996 & 1.077 .876 & 10.562 .049 & 4.900 .058 & 5.835 .014 & 23.065 .465 \\
\hline 1997 & 1.288 .555 & 11.549 .029 & 5.264 .363 & 6.743 .796 & 22.886 .231 \\
\hline 1998 & 1.324 .735 & 10.789 .896 & 4.141 .027 & 5.639 .560 & 17.000 .527 \\
\hline 1999 & 1.401 .884 & 11.549 .269 & 4.207 .492 & 5.972 .734 & 20.076 .356 \\
\hline 2000 & 1.456 .674 & 13.049 .047 & 4.821 .888 & 6.793 .667 & 31.301 .964 \\
\hline 2001 & 1.351 .339 & 12.287 .029 & 4.423 .708 & 7.040 .533 & 25.867 .749 \\
\hline 2002 & 1.371 .651 & 11.889 .909 & 4.836 .639 & 7.564 .887 & 22.440 .868 \\
\hline 2003 & 1.633 .002 & 12.946 .965 & 5.873 .063 & 8.548 .841 & 25.951 .785 \\
\hline 2004 & 1.986 .000 & 15.500 .000 & 7.560 .000 & 12.300 .000 & 34.840 .000 \\
\hline
\end{tabular}

Fonte: Cepal (2004).

Em todo caso, entre 1990 e 2004, as importações dos países andinos mostram uma tendência de aumento (cf. Tabela 11). As curvas são irregulares, mas ascendentes, com exceção talvez da Bolívia depois de 1999. O mesmo pode-se dizer das exportações, com destaque para a Venezuela, a maior exportadora entre os cinco países examinados (cf. Tabela 12). Já a análise da balança comercial demonstra ser na maior parte do tempo deficitária, sobretudo entre 1992 e 1999, menos na Venezuela, onde as exportações são bem superiores e crescem muito acima das importações. O Equador tem obtido pequenos superávits comerciais, embora apresente piora a partir do ano 2000 (cf. Tabela 13).

A análise do comércio exterior andino desde a última década do século XX sugere a existência de um processo de integração internacional desfavorável. As políticas de liberalização têm continuamente ampliado as trocas comerciais sem, no entanto, promover saldos positivos na maioria dos países e dos anos da série histórica. O único desempenho excepcional é mesmo o venezuelano, cujo principal produto de exportação é o petróleo. Nos demais casos, observa-se que o comércio exterior é uma variável que tem tido um papel menos relevante para o desen- 
Tabela 13

Balança Comercial (1990-2004)

\begin{tabular}{c|c|c|c|c|c}
\hline & Bolívia & Colômbia & Equador & Peru & Venezuela \\
\hline 1990 & 220.246 & 1.176 .296 & 852.638 & 678.780 & 10.423 .495 \\
\hline 1991 & -141.681 & 2.277 .289 & 452.321 & -200.469 & 4.144 .148 \\
\hline 1992 & -409.623 & 385.715 & 640.481 & -430.363 & 1.029 .804 \\
\hline 1993 & -425.390 & -2.717 .143 & 509.207 & -846.665 & 3.819 .009 \\
\hline 1994 & -155.735 & -2.795 .540 & 75.399 & -1.267 .189 & 8.318 .571 \\
\hline 1995 & -296.467 & -3.448 .272 & 168.633 & -2.140 .171 & 5.955 .615 \\
\hline 1996 & -565.175 & -3.492 .531 & 968.563 & -1.937 .501 & 13.759 .222 \\
\hline 1997 & -603.477 & -3.931 .789 & 309.694 & -1.620 .921 & 8.640 .579 \\
\hline 1998 & -1.057 .543 & -3.888 .322 & -1.361 .990 & -2.457 .968 & 1.952 .337 \\
\hline 1999 & -696.229 & 890.148 & 1.392 .466 & -558.411 & 6.756 .755 \\
\hline 2000 & -519.937 & 1.510 .537 & 1.253 .188 & -607.104 & 16.023 .857 \\
\hline 2001 & -356.416 & -526.154 & -875.150 & -250.948 & 8.200 .531 \\
\hline 2002 & -398.425 & -778.180 & -1.594 .426 & 73.379 & 11.793 .140 \\
\hline 2003 & 32.220 & 93.624 & -661.337 & -151.358 & 16.916 .711 \\
\hline 2004 & 391.000 & 160.000 & -90.000 & 2.700 .000 & 19.860 .000 \\
\hline
\end{tabular}

Fonte: Cepal (2004).

volvimento, não constituindo um instrumento efetivo de expansão econômica. Sua liberalização exerce pouco impacto sobre a estrutura das economias andinas, que se mantêm primário-exportadoras e altamente dependentes da importação de produtos industrializados.

O índice de liberdade econômica, por seu turno, medido por uma fundação estrangeira (The Heritage Foundation), mostra que a região como um todo tem se mantido na categoria "parcialmente não-livre", girando em torno de 3,1 na média (cf. Tabela 14). Isto significa que, apesar dos esforços de liberalização e de toda a agenda de reformas, incluindo o comércio, os mercados andinos ainda estariam muito fechados. Acima da média, isto é, ainda menos abertos, apenas Venezuela e Equador, outro exportador de petróleo. As economias mais livres seriam, em primeiro lugar, a Bolívia, logo em seguida o Peru (ambas na categoria "parcialmente livre") e, depois, a Colômbia, que pouco variou. Nenhum dos casos andinos, contudo, apresenta uma tendência de liberdade econômica muito bem definida, com exceção da Venezuela, que em 2004 já é considerada uma economia denominada "repressiva" ou não-livre, embora seja o país que mais tenha ampliado suas relações comerciais externas. 
Tabela 14

Índice de Liberdade Econômica (1990-2004)

\begin{tabular}{l|c|c|c|c|c|c|c|c|c|c|c|c}
\hline & $\mathbf{1 9 9 5}$ & $\mathbf{1 9 9 6}$ & $\mathbf{1 9 9 7}$ & $\mathbf{1 9 9 8}$ & $\mathbf{1 9 9 9}$ & $\mathbf{2 0 0 0}$ & $\mathbf{2 0 0 1}$ & $\mathbf{2 0 0 2}$ & $\mathbf{2 0 0 3}$ & $\mathbf{2 0 0 4}$ & $\mathbf{2 0 0 5}$ & Média \\
\hline Bolívia & 3,2 & 2,6 & 2,6 & $\mathbf{2 , 6}$ & 2,6 & $\mathbf{2 , 6}$ & $\mathbf{2 , 3}$ & 2,7 & 2,6 & 2,6 & 2,7 & 2,6 \\
\hline Colômbia & 3,1 & 3,2 & 3,2 & 3,2 & 3,0 & 3,1 & 3,0 & 2,9 & 3,1 & 3,1 & 3,2 & 3,1 \\
\hline Equador & 3,4 & 3,3 & 3,2 & 3,1 & 3,1 & 3,1 & 3,5 & 3,6 & 3,6 & 3,6 & 3,5 & 3,4 \\
\hline Peru & 3,6 & 3,1 & 3,0 & 3,0 & 2,7 & 2,6 & 2,6 & 2,9 & 2,9 & 2,8 & 2,8 & 2,9 \\
\hline Venezuela & 3,3 & 3,6 & 3,6 & 3,4 & 3,5 & 3,4 & 3,8 & 3,9 & 3,7 & 4,2 & 4,1 & 3,7 \\
\hline Região & 3,3 & 3,2 & 3,1 & 3,1 & 3,0 & 3,0 & 3,0 & 3,2 & 3,2 & 3,3 & 3,3 & 3,1 \\
\hline
\end{tabular}

Fonte: The Heritage Foundation (2005). Escala: Livre = 1,99 ou menos; Parcialmente livre = 2,00-2,99; Parcialmente não-livre $=3,00-3,99$; Repressivo $=4,00$ ou mais.

Todos esses dados analisados em conjunto, independentemente de suas classificações, apontam para o fato de que as políticas neoliberais dos anos 1990 não foram responsáveis por todo o mal social nos Andes. Na realidade, a pobreza e a desigualdade são problemas mais antigos e que encontram raízes estruturais na sociedade, tendo sofrido alterações variadas entre os países, nem todas elas necessariamente negativas. No entanto, por outro lado, a agenda de reformas liberalizantes tampouco chegou perto de alcançar os efeitos positivos inicialmente prometidos. A agenda de reformas fundadas no consenso de Washington e defendidas pelos organismos econômicos internacionais reduziu ainda mais as margens de manobra do Estado, reproduzindo seu problema fiscal, em uma espécie de remédio que mantém o paciente inerte.

Além disso, os custos exigidos pela reforma em direção ao mercado, que se refletem, por exemplo, no endividamento público e no aumento do desemprego, superaram muito os seus benefícios, em parte devido a restrições de ordem maior, internacional e sistêmica, em parte porque a liberalização não obedeceu a uma lógica de desenvolvimento. Daí o fato de essas variáveis, liberais e desenvolvimentistas, virem dissociadas na prática, quando teoricamente não estariam. De qualquer forma, o controle inflacionário que contou a favor da adoção dessa agenda transformou-se em ilha de ilusões que encobriu a manutenção de graves deformidades estruturais e assimetrias, entre as quais, uma grande concentração de renda e uma economia primário-exportadora que, na maior parte dos casos, é também deficitária.

Enfim, preservou-se entre os países andinos sua qualidade de subdesenvolvimento mesmo em termos agregados, como demonstra uma análise final da renda per capita entre 1990 e 2004 (cf. Tabela 15). Apenas 


\begin{tabular}{|c|c|c|c|c|c|c|}
\hline \multirow{16}{*}{ 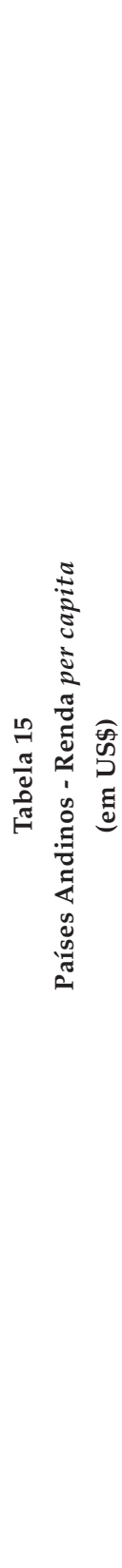 } & ષ્ڤે & $\stackrel{\stackrel{L}{m}}{\sigma}$ & $\left|\begin{array}{c}0 \\
\stackrel{D}{7} \\
\vec{i}\end{array}\right|$ & $\begin{array}{l}\mathrm{J} \\
\mathrm{c} \\
\mathrm{i}\end{array}$ & $\begin{array}{l}\stackrel{\text { }}{+} \\
\stackrel{+}{N}\end{array}$ & $\begin{array}{l}8 \\
\stackrel{8}{0} \\
\stackrel{+}{+}\end{array}$ \\
\hline & ๕్̊ి & ஓ & $\left|\begin{array}{c}2 \\
\infty \\
5 \\
-1\end{array}\right|$ & $\begin{array}{c}\stackrel{0}{二} \\
\stackrel{\vec{v}}{v}\end{array}$ & $\begin{array}{l}\overrightarrow{3} \\
\stackrel{2}{v}\end{array}$ & $\begin{array}{c}\stackrel{d}{d} \\
\stackrel{m}{\oplus} \\
\dot{m}\end{array}$ \\
\hline & ণั̀े & ฉ̊ & $\mid \begin{array}{c}0 \\
\infty \\
\infty \\
-i\end{array}$ & $\begin{array}{l}\vec{\sigma} \\
\overrightarrow{-}\end{array}$ & $\underset{\vec{i}}{\vec{I}}$ & $\begin{array}{l}\vec{b} \\
\stackrel{0}{n} \\
m\end{array}$ \\
\hline & 灾 & 结 & 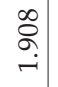 & $\begin{array}{c}\stackrel{+}{\infty} \\
\substack{0 \\
-i}\end{array}$ & $\begin{array}{l}\hat{3} \\
\hat{0} \\
\text { i }\end{array}$ & 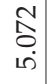 \\
\hline & 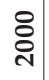 & 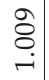 & 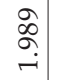 & 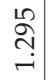 & $\begin{array}{l}\text { f́ } \\
\text { ì }\end{array}$ & $\begin{array}{l}\circ \\
\stackrel{\circ}{\circ} \\
\stackrel{+}{+}\end{array}$ \\
\hline & ڤે & $\stackrel{\Delta}{\sigma}$ & $\begin{array}{l}+ \\
0 \\
0 \\
\dot{N}\end{array}$ & 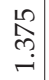 & $\begin{array}{l}\infty \\
\vdots \\
i\end{array}$ & $\begin{array}{l}m \\
\vec{m} \\
\overrightarrow{+}\end{array}$ \\
\hline & $\stackrel{\infty}{\stackrel{2}{\sigma}}$ & $\begin{array}{l}18 \\
0 \\
0 \\
-\end{array}$ & $\begin{array}{l}\vec{J} \\
\stackrel{\mathfrak{J}}{ }\end{array}$ & 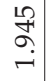 & 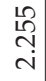 & $\begin{array}{l}\vec{\infty} \\
\stackrel{+}{+} \\
\dot{+}\end{array}$ \\
\hline & ڤે & $\underset{-}{\stackrel{+}{\sigma}}$ & $\begin{array}{l}\infty \\
0 \\
0 \\
ن \\
ن\end{array} \mid$ & 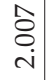 & $\begin{array}{l}\vec{\sigma} \\
\hat{j} \\
\dot{v}\end{array}$ & $\begin{array}{l}1 \\
10 \\
\infty \\
\dot{c}\end{array}$ \\
\hline & よ̊ & $\hat{\circ}$ & 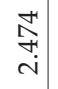 & $\begin{array}{c}\stackrel{1}{\infty} \\
\infty \\
\dot{-}\end{array}$ & $\begin{array}{l}\overrightarrow{5} \\
\text { in } \\
\text { in }\end{array}$ & $\begin{array}{c}\stackrel{\infty}{ড} \\
\stackrel{\dot{m}}{\dot{m}}\end{array}$ \\
\hline & $\begin{array}{l}\stackrel{2}{2} \\
\frac{2}{2}\end{array}$ & $\stackrel{\infty}{\infty}$ & $\begin{array}{l}8 \\
+ \\
+ \\
ن\end{array}$ & $\underset{\sim}{\stackrel{N}{N}}$ & $\begin{array}{l}0 \\
\stackrel{1}{N} \\
\text { N }\end{array}$ & $\begin{array}{l}\vec{b} \\
10 \\
n \\
\infty\end{array}$ \\
\hline & 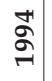 & $\begin{array}{l}\infty \\
\infty\end{array}$ & 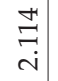 & 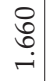 & $\stackrel{\infty}{\sigma}$ & 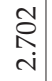 \\
\hline & & 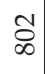 & $\begin{array}{c}0 \\
\tilde{b} \\
-1\end{array} \mid$ & 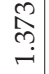 & $\stackrel{+}{\stackrel{+}{n}}$ & $\begin{array}{l}\tilde{a} \\
\infty \\
i\end{array}$ \\
\hline & ล̃ & $\begin{array}{l}\infty \\
\infty\end{array}$ & 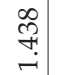 & $\begin{array}{l}\infty \\
\stackrel{2}{\leftrightarrows} \\
\end{array}$ & 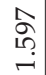 & $\begin{array}{l}\vec{a} \\
\vec{N}\end{array}$ \\
\hline & $\bar{\sigma}$ & $\begin{array}{l}\mathscr{D} \\
\infty \\
\alpha\end{array}$ & $\begin{array}{c}\overrightarrow{\widehat{N}} \\
\text { } \\
-\end{array}$ & $\underset{\square}{\stackrel{\Xi}{\Xi}}$ & 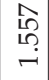 & 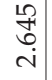 \\
\hline & ஓे & $\stackrel{\curvearrowright}{~}$ & $\mid$\begin{tabular}{l}
10 \\
0 \\
\hdashline \\
-1
\end{tabular} & 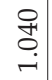 & 苞 & 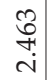 \\
\hline & & 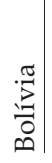 & $\left|\begin{array}{c}\cdot \pi \\
\tilde{Z} \\
00 \\
0 \\
0\end{array}\right|$ & 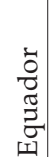 & 窇 & 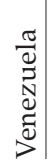 \\
\hline
\end{tabular}


a Venezuela apresentou uma tendência de progresso vigoroso nesse período, ainda que instável e dependente do preço do barril de petróleo. Os demais não experimentaram um salto significativo e ordenado, mantendo-se, com leve melhora neste quesito, após pelo menos $15 \mathrm{ou}$ 20 anos de ajustes econômicos, na categoria de países pobres com renda inferior a US\$2.500 per capita. Um quadro problemático e avanços tão lentos somam-se a um Estado ainda mais combalido, fragmentado e que sofre fortes pressões por democratização, como será observado a seguir.

\section{CONFLITOS E INSTITUIÇÕES POLÍTICAS}

Enquanto a região apresentava poucos avanços na dimensão socioeconômica em direção ao desenvolvimento, no interior das democracias andinas observam-se importantes mudanças políticas. Essas mudanças serão objeto de análise mais cuidadosa nesta seção do trabalho, tomando por base principalmente o banco de eventos organizado pelo OPSA, que traz informações diversas, detalhadas e indexadas sobre episódios políticos ocorridos em cada país da região desde $2001^{1}$.

Primeiramente, é importante salientar a existência de variações e padrões distintos na mudança política de países andinos no fim do século XX. A Colômbia e, sobretudo, a Venezuela foram por muito tempo tidas como modelos de democracia estável na América do Sul. Mesmo que estes países não fossem tão democráticos como se imaginava, ao menos destoavam dos regimes militares espalhados à época pela região. De qualquer forma, nos anos 1990 perderam esse status por razões distintas: os colombianos porque conviveram com o recrudescimento da guerra civil quando menos se esperava que isso fosse ocorrer; e os venezuelanos porque acompanharam o desmanche do seu sistema partidário e a posterior ascensão de Hugo Chávez, uma liderança carismática que entra imediatamente em choque com as forças políticas mais tradicionais do país.

Há décadas a Colômbia arrasta uma das piores guerras civis que já se viu na região. Muito violenta, ela já matou milhares de civis, guerrilheiros e militares. Em 2002, com a eleição do conservador Álvaro Uribe, teve início nova tentativa de pacificação. Apesar de alguns avanços, como a desmobilização parcial das Autodefesas Unidas da Colômbia AUC, negociações com o Exército de Libertação Nacional - ELN e até mesmo com as Forças Revolucionárias da Colômbia - Farc, o problema 
de segurança colombiano ainda impede o fortalecimento das instituições democráticas. A Colômbia caracteriza um tipo de conflito nãoinstitucionalizado, no qual nem todos os atores políticos e sociais aceitam atuar conforme as regras do jogo. A questão central neste país, portanto, continua sendo a falta de adesão plena ao regime político e, conseqüentemente, ao Estado democrático-liberal. Adicionando a isso a herança da militarização e a centralidade assumida pela questão de segurança, tem-se então outro caso bastante particular (cf. Boudon, 2000; Gutiérrez Sanín, 2003; Livingstone, 2004; Safford e Palacios, 2002; Tanaka, 2001).

Parte importante do território colombiano não é controlada pelo Estado, mas pelas guerrilhas, que ainda relutam em aderir às instituições formais do país. Com o fim da União Soviética e da Guerra Fria, essas forças revolucionárias de esquerda perderam sua fonte principal de financiamento. Desde então, elas são acusadas de associarem-se ao narcotráfico para sobreviver, perpetuando, dessa forma, uma luta que já parecia perdida e sem nenhum respaldo internacional. Enquanto isso, a democracia no país permanece instável, refém do passado, mas também de dificuldades econômicas e sociais perenes, que servem de combustível extra para a própria guerra civil.

Já as relações políticas mais institucionalizadas, aquelas que ocorrem dentro do Estado, pouco contribuem para a estabilização do regime. Não apenas estão desconectadas com a realidade violenta do país, como ainda esbarram em disputas ordinárias que fragmentam ainda mais o sistema político. Uma demonstração disso é a criação do partido uribista no fim de 2005. Em função do presidente e das circunstâncias de poder, a direita do país divide-se mais uma vez, constituindo uma nova agremiação que, além de personalista, enfraquece ainda mais os partidos políticos. É importante ressaltar que nas eleições de 2002, pela primeira vez, em décadas, um candidato fora dos grandes partidos colombianos - Partido Liberal - PL e Partido Social Conservador - PSC chega à Presidência do país. Nestas mesmas eleições, os partidos chamados de independentes obtêm um número extraordinário de cadeiras no Legislativo nacional, tanto na Câmara quanto no Senado, acabando com uma maioria unipartidária até então nas mãos do PL.

A Venezuela, por sua vez, tal qual a Colômbia, não passou pela experiência de governos autoritários durante os anos 1960/1970, como, de resto, toda a região. Por 40 anos viveu sobre o pacto do Punto Fijo, um 
acordo realizado em 1958 de alternância entre o Partido Democrático AD e os democrata-cristãos da Comitê de Organização Política Eleitoral Independente-COPEI. Nos anos 1990, este pacto, cuja tentativa de golpe em 1992 é apenas um dos sinais, entra em crise. A partir de então, rumores de novos golpes, revoltas sociais, estados de exceção e processos de interrupção de mandato presidencial tornam-se rotina. Por entre a crise do sistema bipartidário, surge Hugo Chávez, que vence as eleições de 1998 e acelera a derrocada das forças políticas mais tradicionais no país (cf. Burt e Maureci, 2004; Solimano, 2003; Tanaka, 2001; Anastasia, Ranulfo e Santos, 2004).

Em 1999, as mudanças políticas que já se insinuavam ao longo da década iniciam uma nova fase com a escalada da hegemonia chavista sobre o entulho do velho regime, corrompido e desacreditado. Inicialmente, o que se observa é uma feroz luta política entre o grupo de Chávez e as antigas oligarquias, aliadas a sindicatos, que ainda tentavam resistir às mudanças, chegando até mesmo a encampar um golpe de Estado em 2002, que além de fracassar revelou a natureza pouco democrática da oposição. Gradativamente, Chávez vai consolidando e concentrando poder. O embate decisivo foi o referendo de 2004, quando a população, ao não concordar com novas eleições, ratifica uma vez mais seu apoio a Chávez, minando, definitivamente, as forças opositoras.

As oposições ainda tentam deslegitimar as eleições legislativas de dezembro de 2005, retirando-se da competição, mas conseguindo, com isso, apenas a sua auto-exclusão do processo político, sabidamente favorável ao governo. Nesse episódio, a divisão do país, que durante alguns anos flertou com a possibilidade de guerra interna, deflagrando momentos de ruptura institucional, aparentemente perde intensidade e começa a ser colocada em outros termos. Ao mesmo tempo em que a oposição é derrotada, a sociedade revela-se enfastiada com o conflito. Não à toa cresce o grupo dos "ni-ni" - nem chavistas nem antichavistas -, um movimento que surge no referendo de 2004 e que ocupa o centro do espectro político, em uma espécie de síntese do conflito que marcou a passagem de século. No entanto, como este movimento inicialmente não encontra correspondência partidária, o que se constata, na prática, é a consolidação da hegemonia de Chávez.

Hugo Chávez concentrou poderes rompendo a antiga correlação de forças, vencendo eleições locais e nacionais, ampliando sua base de sustentação parlamentar, reformando a Constituição, controlando as 
cortes de Justiça, o Ministério Público, o Conselho Nacional Eleitoral CNE, a polícia, as Forças Armadas, criando novas milícias e as chamadas missões, responsáveis por boa parte da implementação das políticas sociais do governo. Em que pesem as acusações de autoritarismo, fez tudo isso de forma legal e referendada pela população, que o elegeu em 1999, o reconduziu em 2000, o apoiou no referendo de 2004 e deu vitória a seus aliados nas eleições legislativas nacionais de 2005, em uma disputa que os próprios observadores internacionais classificaram como limpa e justa, ao contrário do que afirmou a oposição.

A despeito de Chávez ter realizado todas essas mudanças de maneira formalmente democrática e da oposição ser do tipo oligárquica, nutrir uma cultura golpista e contar com o apoio da mídia privada e a anuência dos Estados Unidos, a nova concentração de poderes introduziu um inequívoco desequilíbrio nos pesos e contrapesos institucionais estabelecidos no país, junto com a possibilidade de violações da liberdade por meio de censura e perseguição política. O caráter popular e hegemônico do governo Chávez interrompeu um modelo político centrado nas elites econômicas e sindicais, liquidando a plutocracia que vigorou por 40 anos na Venezuela, mas também trouxe novos problemas.

Ao mesmo tempo em que o governo promoveu a mobilização e a inclusão política de grande parte da população não-organizada, um ambiente altamente radicalizado levou-o a uma posição de intransigência com relação a seus opositores e a qualquer mecanismo contra-hegemônico. Ademais, a ênfase sobre um modelo de democracia participativa enfraqueceu as instituições representativas e de intermediação que organizavam a vida política do país, verticalizando, assim, um processo de fragmentação que já se havia instalado horizontalmente na sociedade.

Embora existam muitas diferenças nas mudanças políticas observadas na Colômbia e na Venezuela, há algo em comum entre elas: a crise dos partidos tradicionais seguida de uma institucionalidade ainda mais centrada na figura do presidente, seja ele de direita ou de esquerda. Há ainda a semelhança de que, em ambos os casos, essas mudanças no âmbito das instituições, sobretudo partidárias, somaram-se a uma cisão nacional paralelamente conflituosa, com diferenças marcantes de natureza, grau e historicidade. O conflito colombiano é mais antigo (remanescente da Guerra Fria), violento (conflito armado, guerra civil) e foi relativamente atenuado durante o governo Uribe, enquanto o con- 
flito venezuelano é mais novo (pós-Guerra Fria) e menos virulento, embora tenha se intensificado bastante no governo Chávez.

Já mais ao sul dos Andes, observa-se outra mudança política importante na passagem de século. Depois da transição para a democracia, Equador, Peru e Bolívia enfrentam nos anos 1990 o fortalecimento dos movimentos populares; um deles em especial: o movimento de populações tradicionais. Estes países formam o chamado arco indígena, composto, sobretudo, por quéchuas e aymaras. Grande parte das revoltas sociais que eclodem durante todo esse período envolvem tais grupos, que reiniciam uma onda de reivindicações sufocadas pelos governos autoritários (os anos 1990 consolidam o renascimento cultural indígena e revigoram a luta pela terra).

Equador e Bolívia são países que têm movimentos indígenas bastante amplos e atuantes. No Peru, suas demandas misturam-se mais às dos sindicatos e camponeses comuns. Estes movimentos reclamam melhores condições de vida e participação política, passando ainda pela valorização de sua identidade étnica. Suas reivindicações são, portanto, de ordem material, mas também simbólica e política. Elas ajudam a impulsionar um processo de fragmentação e conflito dentro da sociedade e entre a sociedade e o Estado, incluindo conflitos de natureza regional (cf. Burt e Maureci, 2004; Crabtree e Whitehead, 2001; Dávalos, 2005; Martí I Puig e Sanahuja, 2004; Solimano, 2003).

Os conflitos sociais equatorianos e bolivianos guardam algumas semelhanças e, por isso, podem ser analisados conjuntamente até certo ponto. Eles alimentam um quadro crônico de instabilidade política que geralmente se manifesta em revoltas e pressões seguidas de estados de exceção e, por vezes, interrupções de mandatos presidenciais e até mesmo golpes de Estado, a exemplo da deposição do presidente equatoriano Jamil Mahuad em 2000. Tanto no Equador quanto na Bolívia os movimentos indígenas têm despertado grande inquietação nas elites locais, aprofundando uma clivagem social de natureza étnica para além dos conflitos de classe já conhecidos na região. Algumas de suas lideranças mais radicais chegaram ao extremo de propor a formação de um "Estado" indígena que reunisse povos tradicionais à margem das instituições oficiais. Não encontram respaldo para tanto, mas, de qualquer forma, demonstram com isso um profundo desconforto e insatisfação com o Estado vigente, pretendendo a sua superação. 
Esses movimentos foram capazes de eleger presidentes. No Equador, Lúcio Gutiérrez foi eleito em 2003 pela Sociedade Patriótica - SP com uma agenda de mudanças bastante à esquerda e nacionalista, bandeira esta, curiosamente, sensível às organizações indígenas. Embora não fosse de ascendência indígena, Gutiérrez atraiu esses movimentos com um discurso fortemente contra o neoliberalismo e a corrupção. Toma como modelo o próprio venezuelano Hugo Chávez e inflama os povos contra as oligarquias e o imperialismo norte-americano.

No entanto, uma vez no poder, Gutiérrez trai suas promessas de campanha, em um típico caso de policy switch (estelionato eleitoral), com a manutenção de uma agenda liberalizante que ele supostamente deveria combater. Ao fazer isso, a perda de popularidade do presidente é acentuada, tornando-se insustentável a partir do final de 2004, quando tenta modificar a composição da Corte Suprema de Justiça - CSJ. Os protestos intensificaram-se no início de 2005, desrespeitando inclusive o decreto de estado de exceção, um instituto tão utilizado quanto pouco eficaz nos anos 1990 (no Equador, esse mecanismo que suspende temporariamente direitos civis é chamado de estado de emergência). Gutiérrez não suporta as pressões e, após um processo de destituição bastante polêmico, transforma-se em mais um presidente asilado, assim como seus antecessores Abdulá Bucaram e Gustavo Novoa. Em seu lugar, assume Alfredo Palácio, que não demora a se ver também pressionado entre duas forças antagônicas: de um lado, os movimentos sociais, de outro, as elites econômicas, cada qual se apoiando externa e respectivamente nos governos venezuelano, de Hugo Chávez, e norte-americano, de George W. Bush.

Nessa batalha, mais uma vez, vence a manutenção da política econômica herdada das reformas orientadas ao mercado. Vence a continuidade, por exemplo, das negociações em torno de um Tratado de Livre Comércio - TLC com os Estados Unidos, o que leva Palácio a perder sua base de sustentação social recém-conquistada. No meio disso, o novo presidente propõe uma Assembléia Nacional Constituinte com amplos poderes, proposta esta que logo enfrenta grande oposição no Legislativo e no Tribunal Supremo Eleitoral, e lança o país em nova crise, revivendo, assim, uma espiral de conflitos que manteve a rotina de instabilidade na democracia equatoriana sem perspectiva de solução, mesmo a despeito das tentativas institucionais de Palácio refletidas na criação do Sistema de Concertação com a Sociedade Civil e do Conse- 
lho Nacional de Modernização - Conam, órgãos dirigidos ao aperfeiçoamento das relações entre o Estado e a sociedade.

O Equador não tem contado com um corpo estável de regras constitucionais. Já em 1997, realizou-se uma Assembléia Constituinte para a elaboração de uma nova Carta que passaria a regular as práticas políticas do país. Uma rotina de reformas institucionais como esta evidenciou a falta de coesão interna quanto ao marco normativo, configurando-se como elemento central da crise dos partidos e das relações Executivo-Legislativo. A partir de 1994, após consulta popular (mecanismo muito usado), o Equador também experimentou a participação dos independientes ou movimentos sociais (agrupamentos sem requisito de afiliação partidária). A dificuldade em construir maiorias parlamentares e sociais fez com que os presidentes equatorianos dispusessem de períodos relativamente curtos de cooperação com o Congresso, entre um e dois anos, depois dos quais o sistema entrava irremediavelmente em crise.

A Bolívia apresenta um fenômeno semelhante de deterioração do sistema partidário acompanhado por uma escalada de conflitos étnicos, setoriais e entre regiões do país (oriente versus ocidente). Provavelmente é o caso mais claro da força exercida pelos movimentos sociais, sobretudo indígenas, no sentido de aprofundamento da democracia. Da mesma forma, é o caso mais proeminente de demandas por inclusão política, tendo em vista enormes distorções e assimetrias de representação nas instituições estatais, sejam elas legislativas, executivas, judiciais ou mesmo militares, ainda existentes em uma sociedade composta por dois terços de populações indígenas.

Após a transição, o governo de Victor Paz Estenssoro, do Movimento Nacionalista Revolucionário - MNR, forjou um pacto pela democracia com a Ação Democrática Nacionalista - ADN e deu início a um programa de reformas estruturais. Em 29 de agosto de 1985, foi instituído o primeiro ato neoliberal em um governo sul-americano democrático, o decreto 21.060, que obedece a recomendações do Fundo Monetário Internacional (cf. Hofmeister, 2004). Em 1989, definiu-se outro acordo, agora entre ADN e o Movimento da Esquerda Revolucionária - MIR, que elegeu Jaime Paz Zamora (MIR), apesar de não ser o candidato mais votado. Vale salientar que, na Bolívia, caso nenhum dos candidatos consiga a maioria dos votos $(50 \%+1)$ em eleição direta, o Congresso é quem escolhe o presidente em segundo turno, prática que se tornou 
habitual e uma das principais responsáveis pelo déficit de legitimidade dos governos.

A democracia pactuada começou a entrar em crise na Bolívia já no fim dos anos 1990, depois do término do primeiro governo de Gonzalo Sanchez de Lozada (1994-1998). O ressentimento herdado da ditadura contra o novo presidente e ex-general Hugo Banzer (1998-2002), somado à crise econômica e ao auge da campanha de erradicação da coca (cultura tradicional na Bolívia), impulsionou grandes mobilizações sociais, das quais emergiu com vigor o Movimento ao Socialismo-MAS, do cocalero Evo Morales. A partir de então ocorreu uma seqüência de protestos mais intensos: a guerra das águas, em 2000 (quando os movimentos sociais de Cochabamba conseguem impedir a privatização do serviço de distribuição); a guerra do gás que tomou conta do país em 2003, levando à deposição do presidente Sanchez de Lozada (no seu segundo mandato presidencial); e o conflito final, em 2005, cuja renúncia de Carlos Mesa levou à ascensão de um governo provisório, tendo à frente Eduardo Rodrigues (juiz e então presidente da Corte Suprema).

O resultado dessa escalada de conflitos foi a vitória de Evo Morales nas eleições antecipadas de 2005, obtendo a maioria dos votos (51\%) e ampla vantagem sobre o segundo colocado, Jorge Quiroga (Poder Democrático e Social - Podemos). O líder sindicalista e primeiro presidente boliviano de origem indígena conquistou a maioria na Câmara, inaugurando, assim, um novo quadro político na Bolívia. Sobre os escombros dos antigos partidos, nasceu um sistema bipartidário dividido entre o MAS e o Podemos, preservando, contudo, o desafio do governo em conciliar uma enorme lista de demandas sociais que inclui a realização de reforma agrária, uma nova regulamentação quanto à plantação de coca, a nacionalização dos recursos naturais e a convocação de uma Assembléia Constituinte.

Já no Peru, embora tenha também uma grande população indígena, o corte étnico não teve o mesmo peso em sua fragmentação e conflitos como no Equador e, principalmente, na Bolívia, seja porque falte uma organização nacional desse movimento seja porque ele se mistura à luta camponesa peruana de natureza mais classista, setorial ou mesmo regional. De todo modo, a história recente do Peru guarda uma particularidade e diferença com relação a todos os outros andinos; a existência de um governo autoritário após o autogolpe de 1992, perpetrado por Alberto Fujimori já em um contexto em que a democracia é hege- 
mônica na região (Coutinho, 2005; Anastasia, Ranulfo e Santos, 2004; Tanaka, 2001).

A ruptura institucional peruana destoa em sua vizinhança não pelo golpe propriamente, mas porque a ele prosseguiu o endurecimento do regime que se prolongou por toda a década. A fujimorização do Peru assistiu ao fim da guerra civil (uma das mais sangrentas na América Latina), a um processo de deterioração generalizada das instituições e ao domínio da doutrina neoliberal. Com a queda de Fujimori em 2000, Alejandro Toledo do Peru Possível - PP é eleito, herdando um Estado completamente corrompido e uma enorme insatisfação popular que, a partir desse momento, se libera do controle exercido pelo velho regime.

Uma vez no poder, Toledo realiza uma aliança com a Frente Independente Moralizadora - FIM, o que já sinaliza negativamente para os movimentos sociais que o ajudaram a se eleger, uma vez que se tratava de uma coalizão mais à direita. Faz isso para obter uma pequena maioria, arregimentando também apoios circunstanciais de outros partidos menores. Toledo enfrenta sua primeira grande crise em 2002, quando é obrigado a decretar um estado de exceção em certas localidades do país onde há grande agitação nas ruas. Em 2003, deflagra-se outra crise, mais uma vez despertada por revoltas sociais espalhadas por boa parte do país. Novo estado de exceção é decretado e, mais uma vez, os militares saem às ruas para restaurar a ordem.

As crises não cessam, quase todas implicando em reformas no ministério e em ameaças à permanência do presidente. Toledo perde quase todo apoio social. Sua popularidade cai para níveis muito baixos, chegando a $6 \%$ no final de 2004. Na virada de ano, para 2005, ocorre outro levante, agora em forma de quartelada, que as autoridades logo conseguem abafar com novo estado de emergência instituído por Toledo. $\mathrm{O}$ presidente sobrevive a todas essas ondas de protesto e intentonas graças a um grande medo espalhado no país de novo retrocesso institucional, uma vez que a memória de Fujimori continuava viva. Outro fator que mantinha Toledo no cargo era a falta de uma oposição capaz de assumir o país. Nesse momento, o Peru viveu uma espécie de equilíbrio instável à espera das eleições de 2006, enquanto se acomodava o quadro partidário nacional com a emergência de novas lideranças e frentes partidárias, em particular, Lourdes Flores, da Unidade Nacional-UN, e Ollanta Humala, oriundo de um grupo nacionalista mais radical (et- 
nocacerismo). Eles passam a disputar espaços com os antigos partidos Aliança Popular Revolucionária Americana - Apra e Ação Popular $\mathrm{AP}$, liderados, respectivamente, pelos ex-presidentes Alan García e Valentín Paniagua.

Observando comparativamente todos os países andinos, chega-se à conclusão de que, na passagem de século, esteve em andamento um profundo processo de mudança política que se refletiu fortemente no comportamento dos atores políticos e sociais, gerando crises institucionais em todo esse período. Não obstante suas diferenças, que são bastante importantes, a fragmentação e os conflitos apontados em cada um desses países são indícios de um mesmo movimento de democratização que vai de encontro à capacidade de resposta do Estado (capacidade ainda mais reduzida com as reformas em direção ao mercado) em satisfazer os anseios mais populares ou mesmo em coordenar as relações políticas que então emergem.

Essa mudança de comportamento é reveladora de novos valores e elementos presentes na cultura política e que se consolidam, sobretudo, nos anos 2000. Entre eles, merecem destaque os sentimentos étnicos, nacionalistas, antineoliberais e de crítica às instituições políticas tradicionais. Todos esses sentimentos misturam-se em um caldo de cultura que se resume no signo da inclusão, tanto do ponto de vista do agrupamento no Estado quanto da dimensão social de bem-estar. Essa nova constelação de idéias e sentidos, que de alguma forma recupera símbolos antigos, passa a orientar o comportamento político em busca de uma acomodação dificultada pela inépcia do Estado e por um ordenamento econômico que não se limita aos Andes, mas no qual o mercado assume proeminência.

A crise dos partidos políticos é nesse período sintomática do descontentamento com as instituições políticas tradicionais. Os cidadãos sul-americanos compartilham dos princípios e valores democráticos, mas também desconfiam muito fortemente dos políticos, das instituições representativas e das políticas públicas que costumam ser implementadas, o que tem provocado uma baixa preferência pela democracia em toda a região, mas em particular na América Andina, onde haveria a menor proporção de "democratas" segundo o relatório das Nações Unidas sobre o tema (cf. PNUD, 2004). O enfraquecimento ou mesmo o colapso dos partidos hegemônicos e mais antigos na virada de século é, ao mesmo tempo, resultado dessa nova cultura política an- 
dina e ingrediente de instabilidade, uma vez que a ausência de mecanismos de intermediação institucional entre o Estado e a sociedade faz com que as pressões sociais não encontrem um canal de interlocução ou formas de acomodar os conflitos como anteriormente. Tampouco os governos dispõem de atores e instituições com credibilidade junto aos movimentos sociais.

As exceções com relativa reserva de credibilidade social reduzem-se justamente aos novos governos e partidos de caráter mais popular, como o de Chávez e Morales, que ascendem ao poder, em grande medida, devido à nova cultura política emergente em partes da região ${ }^{2}$. Nesses casos, de gobiernos de las calles, nota-se uma tentativa de recuperação das responsabilidades do Estado e uma maior aproximação com setores mobilizados da sociedade e até então marginalizados. Mas, por outro lado, também são crescentes nesses países os embates com as velhas oligarquias e o mercado, o que acaba aprofundando as divisões nacionais e reproduzindo um ambiente de instabilidade. Na Colômbia, é importante salientar, a credibilidade e a aceitação conquistada pelo governo Uribe não atinge todo território nacional, uma vez que grande parte deste ainda está sob o controle de forças subversivas que relutam em legitimar o Estado democrático-liberal. Além disso, o próprio uribismo é prova mais do que suficiente da falência partidária e fragmentação social também observada neste país, apesar de todas as suas excepcionalidades.

\section{CONCLUSÃO}

Com as reformas liberalizantes na última década do século XX e com todas as transformações globais já em andamento, os estados andinos acabaram perdendo poder e autonomia. A crise fiscal do Estado não foi resolvida nesses países e o endividamento público agravou ainda mais o problema. Paralelamente, os mecanismos de controle e intervenção econômica foram reduzidos, sem que, em seu lugar, o mercado oferecesse grandes resultados. Quando, então, a sociedade expande suas expectativas e demandas vis-à-vis o processo de democratização dos regimes políticos e, dessa forma, começa a participar mais livre e ativamente da vida pública, encontra um Estado "esvaziado".

Mesmo com a inclusão política - incorporação de representantes nas instituições e deliberações do Estado -, os graus de liberdade ou as margens de manobra para a promoção de uma maior mudança nas es- 
truturas sociais (no status quo) são muito pequenos. Fica, portanto, a impressão de que se chegou tarde à festa, de tomar parte de um Estado que já desempenhou um papel relevante para o desenvolvimento, mas que agora não dispõe dos poderes de antes, justamente em uma época de retração do capitalismo mundial depois de décadas de forte crescimento.

Essa aparente contradição do Estado democrático-liberal, um Estado que supostamente seria de soberania popular, reserva um trágico período para os países andinos, mergulhados em crises institucionais sucessivas. Seu paradoxo está mesmo na base da insatisfação da maior parte da sociedade, não com as instituições democráticas propriamente ditas, mas com o fato de o poder ter se transferido para fora delas, de não estar mais nos partidos, no Parlamento e mesmo no governo, ou seja, nos fóruns da política por excelência, mas em instituições intangíveis, supranacionais ou simplesmente fora do alcance de nações situadas à margem do novo ordenamento internacional, que nele encontram dificuldade até mesmo para uma inserção periférica como no passado. Em um quadro como esse, em que o espaço político nacional é um lugar de decisões menos efetivo e repleto de expectativas de quem nele ingressa, desenvolve-se um ambiente de perplexidade, apatia e revolta.

Cotejando os países andinos, identifica-se a existência de diferentes processos de fragmentação e conflito movidos por um anseio em comum de inclusão política e social. Os estados andinos contemporâneos dão vazão a essa demanda, realçando formas variadas de comportamento político, mas esbarrando em suas próprias limitações. Estes são problemas de um Estado que, em um só tempo, se politizou, posto que democrático, e perdeu centralidade, posto que se liberaliza. A percepção das diferenças e a mobilização de interesses cultivaram formas distintas de comportamento político, mas todas elas tão desagregadoras quanto imbuídas de um espírito inclusivo. Como o Estado não consegue automaticamente responder às demandas sociais, e tampouco o mercado, deflagra um conflito em busca de nova acomodação, que demora muito a acontecer.

A constatação de não encontrar mais no Estado um instrumento de transformação social, tendo finalmente maior acesso a ele, frustra grande parte da população. Afinal, ao contrário do que esperariam teorias da modernização (cf. Lipset, 1963), trata-se de experiências democráticas sem desenvolvimento, de poliarquias sem resultados concre- 
tos mais animadores. De certo modo, essa discussão ressuscita toda uma linha interpretativa que enxerga na participação um risco para a democracia com o argumento da sobrecarga e questionamento permanente das decisões (cf. Huntington e Nelson, 1976). No entanto, o problema não se reduz apenas ao aumento das demandas, mas refere-se também e principalmente ao lado da oferta, isto é, ao enfraquecimento do poder de resposta das instituições públicas.

Em estudo anterior, constatou-se que a inclusão política foi fundamental para a estabilização de algumas democracias no Cone Sul (cf. Coutinho, 2005). Ela foi responsável por gerar um ambiente mais cooperativo, algo que faltava aos países andinos, ainda pouco inclusivos. Venezuela, Peru e Equador não formavam governos de ampla coalizão, geralmente mantinham maiorias restritas ou ad hoc e estabeleciam um padrão de relacionamento altamente conflituoso e excludente com as oposições, reproduzindo inclusive divisões sociais. Já Colômbia e Bolívia mantinham grandes maiorias legislativas formais, mas falsamente inclusivas, porque não correspondiam à diversidade e aos conflitos mais importantes já existentes na sociedade. Estes foram os dois casos estudados nos quais um padrão de conflito mais clivado requeria uma prévia incorporação de segmentos sociais ao Estado.

Independentemente dessas diferenças relativas à inclusão política, em todos os países andinos observou-se uma grande tensão entre limitações econômicas e democracia, entre, por assim dizer, o mercado e as ruas. As forças de mercado tornaram-se mais complexas e demonstraram baixo rendimento, conforme foi possível verificar nas duas primeiras partes deste artigo. Já as forças sociais, movidas por um anseio de inclusão não somente política, mas também social, intensificaram suas ações, mantendo um alto nível de mobilização e gerando, com isso, muitos conflitos, mais ou menos violentos, dependendo do país e do momento, como ficou mais claro na terceira parte. Esse paralelismo de dois processos de mudança aparentemente refratários resulta em uma instabilidade crônica. E mediante a falta de consensos ou bases mínimas de negociação mais duradoura, o predomínio de um comportamento político orientado ao confronto reforça a busca de alternativas ao paradoxo do Estado democrático-liberal.

Uma questão que merece ainda ser destacada é que as crises institucionais vivenciadas pelas democracias andinas não estiveram sempre associadas a crises econômicas, em seu sentido estrito. Na realidade, não 
foram poucas as ocasiões nas quais uma grande crise eclodiu em meio a um relativo crescimento na economia. Um dos exemplos mais recentes é o Peru durante a segunda metade do governo Toledo, marcada por crises políticas e recuperação econômica. Desse modo, a tensão existente entre democracia e limitações econômicas é mais complexa do que pode parecer a princípio. Os momentos oscilantes e pontuais de expansão do capital não significam que a nova riqueza gerada seja bem distribuída na sociedade e sequer suficiente para amainar o desconforto com uma enorme dívida social acumulada ao longo da história. Seria necessário um crescimento mais vigoroso, sustentado e desconcentrado de renda para atender às expectativas da população. Além disso, a atrofia do papel do Estado, somada a problemas institucionais endógenos verificados, por exemplo, na falência dos sistemas partidários, sugere um vazio ou dificuldades de articulação dos interesses do mercado e da sociedade que não poderiam ser superadas facilmente apenas com picos de crescimento enquanto uma coordenação política inclusiva mais eficiente não resolvesse, ao menos, a dimensão institucional do problema.

Finalmente, é importante ressaltar que as crises contemporâneas não encontraram o mesmo apoio para saídas claramente autoritárias, tipificadas nos anos 1960 e 1970. No pós-Guerra Fria, a interrupção dos processos de democratização ou soluções de conveniência das elites são bem mais difíceis, como ficou evidente no episódio que marcou a recondução de Chávez ao poder a pós o golpe de 2002. O dilema passa a ser outro: como adequar um Estado enfraquecido às exigências da democracia sem reprimi-la e levando em conta o protagonismo assumido globalmente pelo mercado.

Guardadas as devidas distinções, parte do paradoxo salientado neste artigo - em que o comportamento econômico esperado pelo mercado colide com o comportamento político despertado nas ruas - remete a idéias contidas em A Grande Transformação, de Karl Polanyi (1980). Agora, como no passado, simultaneamente à onda liberal ocorre um contramovimento de revitalização da sociedade que passa a exigir que o novo mercado se ajuste a um sistema de proteção social e de direitos coletivos. Trata-se, mais uma vez, portanto, de um choque de princípios que divide e abre um corredor de conflitos na sociedade. A tensão institucional resultante deste choque torna a grande transformação em catástrofe. "A crise fascista do século XX teve origem justamente nesse perigoso impasse" (idem:140). Mas a solução para as contradições de 
um Estado democrático-liberal não se revestiu naquele momento nem se reveste agora, forçosamente, de um significado tão fatalista, podendo caracterizar-se também pelo compromisso, por um pacto de convivência, mesmo que não seja nos termos do que foi o modelo de bem-estar social. O desafio continua, de qualquer forma, com o aprofundamento da democracia.

(Recebido para publicação em junho de 2006)

(Versão definitiva em novembro de 2006)

\section{NOTAS}

1. O OPSA é um núcleo de pesquisa do Iuperj que, entre outras atividades de treinamento, análise e informação, desenvolve um banco de eventos (http:/ / observatorio. iuperj.br).

2. Encontra-se em outro artigo uma discussão mais aprofundada sobre as novas lideranças regionais, populismo, neoliberalismo e a instabilidade democrática observada na América do Sul contemporânea (cf. Coutinho, no prelo). 


\section{REFERÊNCIAS BIBLIOGRÁFICAS}

ANASTASIA, Fátima, RANULFO, Carlos e SANTOS, Fabiano. (2004), Governabilidade e Representação Política na América do Sul. São Paulo, Editora UNESP / Konrad Adenauer.

BANCO MUNDIAL. (2001), Pobreza y Desempleo en América Latina y el Caribe. Disponível em <http: / / www.iadb.org/etica/sp4321 / DocHit.cfm?DocIndex=472>.

. (2004), Indicadores Mundiais de Desenvolvimento. Disponível em $<$ http: / / econ.worldbank.org/external/default/main? menuPK=477704\&page $\mathrm{PK}=64167702 \&$ piPK=64167676\&theSitePK=477688>.

BOUDON, Lawrence. (2000), “Party System Deinstitutionalization: The 1997-98 Colombian Elections in Historical Perspective". Journal of Interamerican Studies and World Affairs, vol. 42, № 3 .

BURT, Jo-Marie e MAURECI, Philip. (2004), Politics in the Andes: Identity, Conflict, Reform. Pittsburgh, University of Pittsburgh Press.

COMISIÓN ECONÓMICA PARA AMÉRICA LATINA Y EL CARIBE - Cepal. (2004), Balance Preliminar de las Economías de América Latina y el Caribe. Santiago, División de Desarrollo Económico, Cepal.

(2005a). Panorama de la Inserción Internacional de América Latina y el Caribe 2004: Tendencias para el 2005. Santiago, División de Comercio Internacional e Integración. Disponível em <http: / / www.eclac.org/cgi-bin/getProd.asp?xml=/ publicaciones/xml/5/22465/P22465.xml\&xsl=/comercio/tpl/p9f.xsl>.

. (2005b). Panorama Social de América Latina 2005. División de Desarrollo Social y la División de Estadística y Proyecciones Económicas, CEPAL. Santiago de Chile. Disponível em <http://www.eclac.org/cgi-bin/getProd.asp?xml=/publicaciones/xml/7/22107/P22107.xml\&xsl=/de/tpl/p9f.xsl>.

(2006). Panorama Social de América Latina (versión preliminar). Disponível em <http://www.eclac.org/cgi-bin/getProd.asp? xml=/publicaciones / xml/ 0/27480/P27480.xml\&xsl=/dds/tpl/p9f.xsl\&base=/tpl/top-bottom.xsl $>$.

COUTINHO, Marcelo Vasconcelos. (2005), Crises Institucionais e Mudança Política na América do Sul. Tese de doutorado em Ciência Política, Iuperj.

(no prelo), "Movimentos de Mudança Política na América do Sul Contemporânea". Revista de Sociologia e Política.

CRABTREE, John e WHITEHEAD, Laurence (eds.). (2001), Towards Democratic Viability: The Bolivian Experience. Hampshire, Palgrave.

DAHL, Robert. (1971), Polyarchy: Participation and Opposition. New Haven, Yale University Press.

DÁVALOS, Pablo. (2005), Pueblos Indígenas, Estado y Democracia. Buenos Aires, CLACSO (Colección Grupos de Trabajo).

GUTIÉRREZ SANÍN, Francisco. (2003), “Hyper-Fragmentation and Traditional Politics in Colombia: Discussing Alternative Explanations". Working Paper, no 24, IEPRI, Universidad Nacional de Colombia. 
HOFMEISTER, Wilhelm. (2004), “Bolívia: La Construcción de la Democracia y la Evolución del Proceso Politico", in W. Hofmeister (org.), Reformas Políticas en América Latina. Rio de Janeiro, Fundação Konrad Adenauer.

HUNTINGTON, Samuel P. e NELSON, Joan. (1976), No Easy Choice: Political Participation in Developing Countries. Cambridge, Harvard University Press.

LIPSET, Seymour M. (1963), The Political Man. New York, Doubleday.

LIVINGSTONE, Grace. (2004), Inside Colombia: Drugs, Democracy and War. New Jersey, Rutgers University Press.

MARTÍ I PUIG, Salvador e SANAHUJA, Josep M. (eds.). (2004), Etnicidad, Autonomía y Governabilidad en América Latina. Salamanca, Ediciones Universidad de Salamanca.

ORGANIZACIÓN INTERNACIONAL DEL TRABAJO - OIT. (2005), Panorama Laboral de América Latina y el Caribe 2005 (avance primer semestre). Lima, Oficina Regional para América Latina y el Caribe.

PROGRAMA DAS NAÇÕES UNIDAS PARA O DESENVOLVIMENTO - PNUD. (2004), Democracia na América Latina: Rumo a uma Democracia de Cidadãs e Cidadãos. São Paulo, $\mathrm{LM} \& \mathrm{X}$

POLANYI, Karl. (1980), A Grande Transformação: As Origens da Nossa Época. Rio de Janeiro, Campus.

SAFFORD, Frank e PALACIOS, Marco. (2002), Colombia: Fragmented Land, Divided Society. Oxford, Oxford University Press.

SOLIMANO, Andrés. (2003), "Governance Crises and the Andean Region: A Political Economy Analysis". Santiago, Economic Development Division/Cepal (Macroeconomía del desarrollo series). Disponível em <http://www.eclac.org/publicaciones/ xml/2/12092/lcl1860i.pdf>.

TANAKA, Martín. (2001), La Situación de la Democracia en Colombia, Perú y Venezuela a Inicios de Siglo. Lima, Comisión Andina de Juristas. Disponível em $<$ http:/ /www.observatorioandino.org.co/docs/demo_col_peru_ven.pdf $>$.

THE HERITAGE FOUNDATION. (2005), Index of Economic Freedom. Disponível em $<$ http://www.heritage.org $>$.

UNITED NATIONS. (2005), World Development Report 2006: Equity and Development. New York, WB \& Oxford University Press. 
ABSTRACT
Andean Democracies: Late to the Party?

After a centuries-old history of oligarchic, populist, and authoritarian institutionality, in recent decades South America has begun the transition to a liberal democratic state model. This new state model harbors the contradiction of being both more democratic and less capable. Namely, it allows public participation and dissent, but with more limited conditions to respond, a role that has been largely transferred to the market, which has become globalized and more complex, while experiencing difficulties in meeting social demands. The tension between democracy and economic limitations, combined with endogenous institutional problems, has sustained a climate of permanent political instability in parts of South America, reproducing fragmentations and conflicts, which are the focus of this study, a comparative analysis of five Andean countries: Bolivia, Peru, Ecuador, Colombia, and Venezuela.

Key words: Andean countries; political instability; social fragmentation

\section{RÉSUMÉ}

Démocraties des Andes: Arrivant Trop Tard à la Fête?

Après une histoire centenaire sous la primauté des institutions oligarchiques, populistes et autoritaires, l'Amérique du Sud semble, depuis quelques décennies, aller vers un État démocratique et libéral. Ce nouveau modèle d'État présente le paradoxe d'être plus démocratique sous certains aspects, tout en étant moins efficace, c'est-à-dire qu'il permet la participation et la contestation publique sans pour autant disposer de moyens pour les satisfaire; ceci car presque tous ces moyens ont été cédés au marché économique, qui s'est mondialisé et devenu plus complexe, n'ayant plus la possibilité de répondre aux demandes sociales. La tension entre démocratie et restrictions économiques, associée à des problèmes institutionnels endogènes, provoque un climat d'instabilité politique permanent dans certains endroits de la région, reproduisant des cassures et des conflits, sujet étudié dans cet article sous la forme d'une analyse comparative de cinq pays andins: Bolivie, Pérou, Équateur, Colombie et Vénézuéla.

Mots-clé: pays andins; instabilité politique; éclatement sociale 